\title{
Cultivar Decline in Sweetpotato: II. Impact of Virus Infection on Yield and Storage Root Quality in 'Beauregard' and 'Hernandez'
}

\author{
A.D. Bryan and J.R. Schultheis \\ Department of Horticultural Science, North Carolina State University, Raleigh, NC 27695 \\ Z. Pesic-VanEsbroeck \\ Department of Plant Pathology, North Carolina State University, Raleigh, NC 27695 \\ G.C. Yencho ${ }^{1}$ \\ Department of Horticultural Science, North Carolina State University, Raleigh, NC 27695
}

\begin{abstract}
AdDitional INDEX woRDs. Ipomoea batatas, Sweet potato feathery mottle virus, potyviruses, micropropagation, meristemtip culture

Abstract. To determine the effects of Sweet potato feathery mottle virus (SPFMV), and possibly other newly described potyviruses, on sweetpotato yield and storage root appearance, virus-indexed 'Beauregard' and 'Hernandez' mericlones testing free of known viruses were compared with virus-infected mericlones in two separate experiments over two years. The experiments were arranged in a split-plot, randomized, complete-block design with the initial presence (VI+) or absence (VI-) of SPFMV as the whole plot factor and mericlone as the subplot factor. Plants were monitored weekly for symptoms of SPFMV and vine samples were taken for virus-indexing on Ipomoea setosa. Additional testing for selected sweetpotato viruses was done using a nitrocellulose membrane enzyme-linked immunosorbant assay. SPFMV was the only virus detected in the study, using available testing methodologies. Field monitoring indicated that $\approx 100 \%$ of the VI- plants were reinfected with SPFMV by 9 weeks after planting. The presence of virus before planting reduced yields of No. 1 roots by $26 \%$ and decreased overall appearance ratings for the three 'Beauregard' mericlones. In addition, VI+ planting materials resulted in increased storage root length and reduced storage root width of both cultivars leading to increased storage root length/diameter ratios, further detracting from overall storage root appearance. The results of this study demonstrate that SPFMV contributes to cultivar decline in sweetpotato. However, the interaction of SPFMV with other newly described potyviruses, which may result in synergistic negative effects on sweetpotato yield and quality, needs further research.
\end{abstract}

Decline in yield and root quality in sweetpotato has been attributed to the accumulation of mutations and viruses (Clark et al., 2002; Dangler, 1994; Villordon and La Bonte, 1995, 1996). In the United States and other mild temperate climates where sweetpotato is produced, growers save seed roots from each crop. In early spring, seed roots are planted in beds, and adventitious sprouts from bedded roots are cut and transplanted to the field to produce the sweetpotato crop (Wilson and Averre, 1989). The disadvantage of this method of propagation is that mutations and viruses acquired by sweetpotato plants during the previous growing season will be present in the storage roots, and consequently, in the adventitious sprouts produced.

Adventitious sprouts of sweetpotato storage roots, which are used as planting materials for subsequent crops, have higher phenotypic variability than planting materials derived from nodal stem cuttings of sweetpotato, and this may contribute to decreases in yield and root quality of sweetpotato (Templeton-Somers and

Received for publication 8 Jan. $=2003$. Accepted for publication 2 June 2003 . This paper is a portion of a thesis submitted by Adrienne D. Bryan. The research was supported by the N.C. Agricultural Foundation, the N.C. Crop Improvement Association, the N.C. SweetPotato Commission, and the N.C. Certified Sweetpotato Seed Growers Association. We thank Marilyn Daykin for assistance with meristem-tip culture procedures, Lauren Hix and Jennifer Smith for assistance with greenhouse and field work, Charles Averre, Kenneth Pecota, and Dennis Adams for assistance with harvests and evaluations, Sandy Barnes and Randy Herring and the staff of the Cunningham Research Station, Kinston, NC, for managing the field trials and assisting with harvest. We also thank Christopher Clark, Louisiana State University for reviewing the manuscript and providing timely information on sweetpotato viruses in the U.S.

Corresponding author; e-mail Craig_Yencho@ncsu.edu.
Collins, 1986; Villordon and La Bonte, 1995; 1996). Likewise, adventitious sprouts of sweetpotato infected with virus and nodal cuttings infected with virus yield less than nonsymptomatic sweetpotato planting materials that were virus-indexed (i.e., tested free of known viruses). Viruses that have been found to reduce yield in sweetpotato include Sweet potato feathery mottle virus (SPFMV) (Olivero and Oropeza, 1985; Pozzer et al., 1995), Sweet potato virus disease [a synergistic interaction between SPFMV and Sweet potato chlorotic stunt virus (SPCSV)] (Mukiibi, 1977; Hahn, 1979; Ngeve, 1990; Ngeve and Bouwkamp, 1991), a combination of SPFMV and Sweet potato sunken vein virus (a synonym for SPCSV) (Milgram et al., 1996), and a combination of SPFMV and Sweet potato latent virus (Liao et al., 1983).

SPFMV is the most common virus infecting sweetpotato in the United States and it is found nearly everywhere sweetpotatoes are grown (Clark and Moyer, 1988). It is nonpersistently transmitted by aphids (e.g., Myzus persicae, Aphis gossypii). Foliar symptoms include veinal chlorosis and feathering, and chlorotic spots with purple borders that appear mostly on older leaves of sweetpotato. Storage root symptoms may include russet crack, internal cork, shape deformities, and surface discoloration depending on the cultivar and virus strain present (Moyer and Salazar, 1989). Cultivars released in the United States over the last 20 years appear to have a high level of tolerance to strains of SPFMV found in the United States (Moyer and Salazar, 1989). However, the extent of the decline in yield and storage root quality of sweetpotato attributable to SPFMV and other sweetpotato viruses recently reported in the United States (Moyer et al., 2002) is unclear.

The cultivar Beauregard, released in 1987 by Louisiana State 
University (Rolston et al., 1987), is susceptible to SPFMV. The use of micropropagation, which eliminates viruses through meristemtip culture, has been incorporated into several state sweetpotato seed certification programs to produce high quality virus-tested seedstock for growers (Dangler, 1994). The use of virus-tested stock has been found to reduce the occurrence of SPFMV symptoms in the cultivar Beauregard while providing superior planting material that yields as well or better than nonmicropropagated, virus-infected plants that have been in field production for several years (Averre et al., 1993; Bryan 2002; Jester et al., 1994; Schultheis, 1994; Schultheis et al., 1994).

Studies conducted to compare sweetpotato planting materials derived from micropropagated, virus-indexed mericlones increased in the greenhouse via vegetative nodal cuttings versus seed produced from adventitious sprouts have been conducted (Bryan, 2002; Bryan et al., 2003). This research has demonstrated that a significant decline in yield and storage root quality occurs after the first adventitious propagation cycle. Further, yield and quality continue to decline gradually. The significant decline in yield and root quality after the first adventitious propagation cycle may be due to virus and pathogen infection and/or the increased variability due to mutation accumulation in adventitious propagules (Clark et al., 2002). However, the relative importance of mutations and virus infection and their corresponding effects on yield and root quality remains unresolved. This study was designed to determine the relative importance of viruses in mediating sweetpotato cultivar decline. Specifically, our objectives were to determine the effects of SPFMV on the yield and storage root quality of micropropagated sweetpotato cultivars Beauregard and Hernandez, the two predominant cultivars produced in the United States. Because the planting materials used for this study were derived from micropropagated, nodal cuttings of the same mericlones of 'Beauregard' and 'Hernandez', differences in yield and root quality can be attributed to virus infection greatly reducing the chances of phenotypic variability due to adventitious propagation.

\section{Materials and Methods}

Field trials comparing virus-indexed, micropropagated sweetpotato plants to micropropagated sweetpotato plants infected with SPFMV were conducted in 2000 and 2001 at the North Carolina State University (NCSU), Cunningham Research Station, Kinston, N.C.

Plant material. 'Beauregard' clones B94-14, B94-34, and B73 and 'Hernandez' clones H98-7, H98-9, and USDA were used in the study. The history of the B94-14 and B94-34 clones, which were derived from superior hill selections made in 1994 from the 'Beauregard' clone B73 are described by Bryan et al. (2003). The 'Hernandez' selections H98-7 and H98-9 were derived from superior hill selections made in a grower's field (Mr. Clay Strickland, Spring Hope, N.C.) in 1998 from 'Hernandez,' which was released by Louisiana State University in 1992 (La Bonte et al., 1992), while the USDA 'Hernandez' was obtained from in vitro stocks submitted by LSU and maintained by the USDA-ARS Plant Genetic Resources Conservation Unit in Griffin, Georgia.

The 'Beauregard' and 'Hernandez' clones were placed into the NCSU Micropropagation Unit (MPU) in 1994 and 1997, respectively. Meristem-tip culture and virus-indexing (testing to determine if the materials were free of known viruses) was conducted according to the Food and Agriculture Organization of the United Nations and International Board for Plant Genetic Resources guidelines (Moyer et al., 1989). The virus-tested, vegetative planting stock was maintained in insect-free cages to avoid virus reinfection.

INOCULATION. The virus inoculum used for graft-inoculations in the study was obtained from twelve 'Beauregard' sweetpotato plants expressing symptoms of SPFMV. The plants were obtained from the NCSU Sandhills Research Station, Jackson Springs, N.C. in 1998. The infected 'Beauregard' sweetpotato plants were grafted onto Ipomoea setosa to confirm the presence of virus, and tested for SPFMV, Sweet potato mild mottle virus (SPMMV), Sweet potato latent virus (SwPLV), Sweet potato chlorotic fleck virus (SPCFV), Sweet potato mild speckling virus (SPMSV), C-6 virus, SPCSV, and Sweet potato caulimo-like virus (SPCaLV) using a nitrocellulose membrane enzyme-linked immunosorbant assay (NCM-ELISA) kit provided by the International Potato Center (CIP) in Lima, Peru. Both the virus-indexing and NCM-ELISA tests conducted confirmed that SPFMV was present in the 12 infected 'Beauregard' plants. Newly characterized potyviruses infecting sweetpotato in the United States, including Sweet potato virus $G$ (SPVG) and Ipomoea vein mosaic virus (IVMV), (Moyer et al., 2002; Souto et al., 2003) may have been present in the source material obtained from the original twelve 'Beauregard' sweetpotato plants expressing symptoms of SPFMV; however, reliable testing procedures for these new viruses were not available during this study, so we cannot exclude this possibility.

In March 2000, 25 two-node cuttings were obtained from the mother plants from each of the 'Beauregard' mericlones: B94-14, B94-34, and B-73; and 'Hernandez' mericlones: H98-7, H98-9, and USDA. The cuttings were established in $200 \mathrm{~cm}^{3}$ cells of a 25-cell tray IPL Rigi-Pots (model IP200; Stuewe \& Sons, Inc., Corvallis, Ore.), containing moist Metro-Mix (The Scotts Co., Marysville, Ohio). Plants were grown in the greenhouse at 25 to $28^{\circ} \mathrm{C}$, and watered as needed. When the plants were $\approx 20 \mathrm{~cm}$ in length, each of the 25 plants of each mericlone was graft-inoculated with a 5-cm stem scion of the SPFMV-infected 'Beauregard' plant described earlier. A side-veneer graft procedure was used (Hartman et al., 1997). The incision for the scion was made $\approx 2.5$ $\mathrm{cm}$ from the stem base of the micropropagated mericlones and foliar symptoms were recorded 4 weeks after grafting (WAG).

Greenhouse increase. Two-node cuttings were taken from virus-indexed, micropropagated mother plants of each mericlone and from SPFMV graft-inoculated micropropagated mericlones and established in cells of IPL Rigi-Pots filled with moist MetroMix, as described previously. Each cut was made with a sterile, single-edge, razor blade. Established cuttings were watered daily. When the cuttings formed roots and new shoots, they were fertilized with Miracle Gro 15-30-15 All Purpose water soluble fertilizer (The Scotts Co., Marysville, Ohio) biweekly and plant numbers were increased through repeated two-node cuttings with the cuttings being rooted in a cell of IPL Rigi-Pots. Mericlones of micropropagated, virus-indexed cuttings testing negative for SPFMV (VI-) were grown in screen cages to prevent the introduction of aphids and potential virus infection. The graft-inoculated, SPFMV-infected micropropagated cuttings (VI+) of each mericlone were kept in a separate greenhouse. Cuttings used for the greenhouse increases of both VI- and VI+ plants were taken from their respective mother plants both years of the study.

Trial DESIGN. Field trials were arranged in a split-plot randomized complete block design with SPFMV presence or absence (VI+/VI-) as the whole plot factor and mericlones as the subplot factor with five replications. The 'Beauregard' and 'Hernandez' 
trials were planted and analyzed separately for both 2000 and 2001. The trials were located at the Cunningham Research Station, Kinston, N.C. The soil series and texture for each trial in both years was a Norfolk loamy sand (fine-loamy, kaolinitic, thermic Typic Kandiudults).

The 'Beauregard' trial in 2000 was planted on 8 June and harvested on 28 Sept., $112 \mathrm{~d}$ after planting (DAP). The 'Hernandez' trial in 2000 was planted on 8 June and harvested on 16 Oct. (130 DAP). In 2001, both 'Beauregard' and 'Hernandez' trials were planted 21 June and harvested 9 Oct. (108 DAP). In 2000, plots were $5 \mathrm{~m}$ in length and rows were formed on $1.1 \mathrm{~m}$ centers. In 2001, plots were $6.1 \mathrm{~m}$ in length and rows were formed on 1.1 m centers. Each plot included 20 plants in 2000 and 25 plants in 2001 , spaced $23 \mathrm{~cm}$ apart for 'Beauregard' mericlones and spaced $30 \mathrm{~cm}$ apart for 'Hernandez' mericlones. Border plants of the VI- white skinned sweetpotato cultivar O'Henry were included at the end of plots at the same spacing to minimize border effects and delineate the plots. In 2000, border rows were included as a single row on each side of the 'Beauregard' and 'Hernandez' trials and as two rows between whole plots within each trial. Plants for border rows were nonmicropropagated 'Beauregard', maintained by the NCSU Sweetpotato Breeding and Genetics Program. The plants for border rows were spaced $23 \mathrm{~cm}$ apart in the row. In 2001, border rows of VI- plants of 'Beauregard' and 'Hernandez' mericlones were spaced $23 \mathrm{~cm}$ and $30 \mathrm{~cm}$ apart, respectively. These cultivars were included as border row plants in the same manner as the 2000 trials for each trial of 'Beauregard' and 'Hernandez.' Each trial was planted by hand.

The fertility regime included two cultivations at $\approx 1$ and 4 weeks after planting (WAP). Fertilizer application of $30 \mathrm{~kg} \cdot \mathrm{ha}^{-1}$ of $\mathrm{P}$, $140 \mathrm{~kg} \cdot \mathrm{ha}^{-1}$ of $\mathrm{K}$, and $1.1 \mathrm{~kg} \cdot \mathrm{ha}^{-1}$ of B was incorporated into the first cultivation and $52 \mathrm{~kg} \cdot \mathrm{ha}^{-1}$ of $\mathrm{N}$ into the second cultivation. At harvest, sweetpotatoes were graded according to U.S. National Sweetpotato Collaborator standards, which classify harvested roots into U.S. No. 1 roots (diameter of 5 to $<9 \mathrm{~cm}$ and length of 7.5 to $<23 \mathrm{~cm}$ ), canner roots (diameter of 2.5 to $<5 \mathrm{~cm}$ and length of 5 to $<18 \mathrm{~cm}$ ), jumbo roots (diameter $>9 \mathrm{~cm}$, or length $>23 \mathrm{~cm}$ ), and cull roots (malformed or distorted roots).

Yield measurements were recorded for each grade, including total marketable yield (TMY), which includes all grades except culls. The percentage of No. 1 roots (percent No. 1s) was calculated relative to the total yield for each plot. The length and diameter of each No. 1 root was measured for each treatment and for comparison of length to diameter (L/D) ratios. Lengths of roots were measured to the nearest $\mathrm{cm}$ and included only 2.5 $\mathrm{cm}$ of ends less than $1 \mathrm{~cm}$ in diameter. Width was measured in $\mathrm{cm}$ at the midpoint of the length measurement. Four researchers (the authors) evaluated the root quality of the collective total No. 1 roots for each treatment, including overall appearance and shape uniformity. Root quality measurements were recorded on a 0 to 5 scale to the nearest half unit where 5 represents the best overall uniformity and appearance.

VIRUS MONITORING. In both years foliar symptoms typical of SPFMV and other potyviruses appeared on the graft-inoculated (VI+) plants from which cuttings were made before planting. However, due to new growth of sweetpotato and dropping of older SPFMV symptomatic leaves, VI+ plants were not symptomatic shortly after planting in 2000 and 2001. Monitoring of SPFMV symptom expression in VI+ plants and infection of VI- plants was conducted on a weekly basis, beginning 4 WAP for the 'Beauregard' and 'Hernandez' tests in 2000 and 1 WAP for the 'Beauregard' and 'Hernandez' tests in 2001.
Weekly observations of the number of symptomatic plants were recorded for each plot. Before harvest, symptomatic vines $(\approx 30 \mathrm{~cm}$ in length) of three randomly selected plants were chosen from each plot (15 plants total per treatment) and grafted onto the indicator plant, Ipomoe a setosa, to test for the presence of viruses. These indicator plants were then tested for SPFMV, SPMMV, SwPLV, SPCFV, SPMSV, C-6 virus, SPCSV, and SPCaLV using a NCM-ELISA kit provided by the International Potato Center (CIP) in Peru.

Statistical analysis. For each year, yields of graded roots, measurements of root quality, $\mathrm{L} / \mathrm{D}$ ratios of roots and the weekly percentage of SPFMV symptomatic plants were recorded and analyzed for each test using the SAS General Linear Models procedure (SAS Institute, 1998). Mean separation was conducted using Fisher's Protected Least Significant Difference (LSD) test for yield and root quality measurements comparing VI-and VI+ plants between each mericlone and VI- and VI+ plants averaged over all mericlones for each cultivar. Mean separation for L/D ratios of $\mathrm{VI}-$ and VI+ plants of each mericlone was conducted using tests for differences between least squares means (LSMEANS).

\section{Results}

2000. Averaged across all 'Beauregard' mericlones, planting materials testing negative for SPFMV(VI-) produced higher yields of No. $1 \mathrm{~s}$ and percent No. 1s $(p=0.05)$ and TMY $(p=0.1)$, and fewer culls $(p=0.1)$ and jumbos $(p=0.05)$ than SPFMV infected (VI+) planting materials (Table 1 ). Yields of No. 1 roots and percent No. 1 roots produced by VI+ plants of 'Beauregard' were reduced by $26 \%$ and $24 \%$, respectively, compared to VI- plants. Jumbo and cull yields were increased by $119 \%$ and $90 \%$, respectively, comparing VI+ and VI- planting materials. Compared to VI+ planting materials, 'Beauregard' VI- plants also produced roots with better overall appearance ratings $(p=0.05)$.

Differences or trends in yield and root quality attributes between VI- and VI+ plants for each mericlone were generally consistent with those found between VI- and VI+ plants averaged across 'Beauregard' mericlones. For instance, VI-plants of B94-34 and B94-14 produced greater yields of No. 1 roots than B94-34 VI+ plants $(p=0.05)$ and B94-14 VI+ plants $(p=0.1)$. The same trend was observed between VI- and VI+ planting materials of B73, but it was not statistically significant. Similarly, differences in yield of culls were generally consistent between VI- and VI+ plants for each 'Beauregard' mericlone. Planting materials of VI-B94-14 and B73 produced fewer culls than infected planting materials, while VI- and VI+ plants of B94-34 produced a similar amount of culls. Storage roots of B73 derived from VI+ planting materials had lower shape uniformity ratings than those derived from VI-planting materials. This relationship was consistent, but not detected statistically, between VI- and VI+ storage roots of B94-14 and B94-34. For diameter and L/D ratio measurements, differences were found in all three mericlones with storage roots derived from VI- planting materials being wider in diameter and lower in L/D ratios than VI+ storage roots (Table 2). Additionally, the storage roots of B94-14 and B-73 obtained from VI-planting stock were longer than those obtained from VI+ plants.

In the 'Hernandez' test, averaged across the three mericlones, the VI- planting materials produced higher yields $(p=0.05)$ of No. 1 and percent No. 1 roots, and fewer canner roots than VI+ plants (Table 1). Yields of No. 1 and percent No. 1 roots of the 'Hernandez' mericlones were reduced $22 \%$ and $20 \%$, respectively, for the crop obtained from VI+ planting materials, and canner 
Table 1. Yield and root quality measurements for 'Beauregard' and 'Hernandez' mericlones in field trials in 2000 (Cunningham Research Station, Kinston, N.C.). ${ }^{z}$

\begin{tabular}{|c|c|c|c|c|c|c|c|c|c|c|}
\hline \multirow[b]{3}{*}{ Mericlone } & \multirow[b]{3}{*}{ SPFMVw } & \multirow{2}{*}{\multicolumn{7}{|c|}{ Yieldx }} & \multicolumn{2}{|c|}{ Root quality } \\
\hline & & & & & & & & & \multirow{2}{*}{$\begin{array}{c}\text { Shape } \\
\text { uniformity }\end{array}$} & \multirow{2}{*}{$\begin{array}{c}\text { Overall } \\
\text { appearance }\end{array}$} \\
\hline & & Total & TMY & No. 1 & Canners & Jumbos & Culls & No. $1(\%)$ & & \\
\hline \multicolumn{11}{|l|}{$\overline{\text { Beauregard }}$} \\
\hline B94-14 & VI+ & $29.0 \mathrm{~A} \mathrm{a}$ & $22.0 \mathrm{~A} \mathrm{a}$ & $14.6 \mathrm{~A} \mathrm{~b}$ & $3.8 \mathrm{~A} \mathrm{a}$ & $3.6 \mathrm{~A} \mathrm{a}$ & $7.0 \mathrm{~B} \mathrm{~b}$ & $50.1 \mathrm{~B} \mathrm{~b}$ & $2.6 \mathrm{~A} \mathrm{a}$ & $2.5 \mathrm{~A} \mathrm{~b}$ \\
\hline \multirow[t]{2}{*}{ B94-34 } & VI- & $32.9 \mathrm{~A} \mathrm{a}$ & $29.8 \mathrm{~A} \mathrm{a}$ & $23.3 \mathrm{~A} \mathrm{a}$ & $5.2 \mathrm{~A} \mathrm{a}$ & $1.2 \mathrm{~A} \mathrm{a}$ & $3.0 \mathrm{~A} \mathrm{a}$ & $70.9 \mathrm{~A} \mathrm{a}$ & $3.5 \mathrm{~A} \mathrm{a}$ & $3.6 \mathrm{~A} \mathrm{a}$ \\
\hline & VI+ & $27.5 \mathrm{~B} \mathrm{~b}$ & $26.0 \mathrm{~A} \mathrm{a}$ & $14.0 \mathrm{~B} \mathrm{~b}$ & $8.4 \mathrm{~A} \mathrm{a}$ & $3.6 \mathrm{~A} \mathrm{a}$ & $1.5 \mathrm{~A} \mathrm{a}$ & $49.5 \mathrm{~A} \mathrm{~b}$ & $3.4 \mathrm{~A} \mathrm{a}$ & $2.7 \mathrm{~A} \mathrm{a}$ \\
\hline B73 & VI+ & $28.8 \mathrm{~A} \mathrm{a}$ & $25.9 \mathrm{~A} \mathrm{a}$ & $18.2 \mathrm{~A} \mathrm{a}$ & $4.5 \mathrm{~A} \mathrm{a}$ & $3.2 \mathrm{~A} \mathrm{a}$ & $2.9 \mathrm{~A} \mathrm{~b}$ & $62.8 \mathrm{~A} \mathrm{~b}$ & $3.2 \mathrm{~B} \mathrm{~b}$ & $3.1 \mathrm{Ab}$ \\
\hline \multirow[t]{2}{*}{ Mean } & VI- & $29.6 \mathrm{~A} \mathrm{a}$ & $27.6 \mathrm{~A} \mathrm{a}$ & $21.1 \mathrm{~A} \mathrm{a}$ & $5.6 \mathrm{~A} \mathrm{a}$ & $1.6 \mathrm{~A} \mathrm{a}$ & $2.0 \mathrm{~A} \mathrm{a}$ & $71.4 \mathrm{~A} \mathrm{a}$ & $3.5 \mathrm{~A} \mathrm{a}$ & $3.5 \mathrm{~A} \mathrm{a}$ \\
\hline & VI+ & $28.4 \mathrm{~A} \mathrm{a}$ & $24.6 \mathrm{~A} \mathrm{~b}$ & $15.6 \mathrm{~B} \mathrm{~b}$ & $4.9 \mathrm{~A} \mathrm{a}$ & $3.5 \mathrm{~B} \mathrm{~b}$ & $3.8 \mathrm{~A} \mathrm{~b}$ & $54.2 \mathrm{~B} \mathrm{~b}$ & $3.1 \mathrm{~A} \mathrm{a}$ & $2.8 \mathrm{~B} \mathrm{~b}$ \\
\hline \multicolumn{11}{|l|}{ Hernandez } \\
\hline \multirow[t]{2}{*}{ H98-7 } & VI- & $30.4 \mathrm{~A} \mathrm{a}$ & $29.3 \mathrm{~A} \mathrm{a}$ & $21.2 \mathrm{~A} \mathrm{a}$ & $5.3 \mathrm{~A} \mathrm{a}$ & $2.8 \mathrm{~A} \mathrm{a}$ & $1.2 \mathrm{~A} \mathrm{a}$ & $69.6 \mathrm{~A} \mathrm{a}$ & $2.9 \mathrm{~A} \mathrm{a}$ & $2.8 \mathrm{~A} \mathrm{a}$ \\
\hline & VI+ & $26.0 \mathrm{~A} \mathrm{a}$ & $24.6 \mathrm{~A} \mathrm{a}$ & $14.8 \mathrm{~A} \mathrm{~b}$ & $7.2 \mathrm{~B} \mathrm{~b}$ & $2.6 \mathrm{~A} \mathrm{a}$ & $1.5 \mathrm{~A} \mathrm{a}$ & $54.7 \mathrm{~A} \mathrm{~b}$ & $3.4 \mathrm{~B} \mathrm{~b}$ & $2.8 \mathrm{~A} \mathrm{a}$ \\
\hline \multirow[t]{2}{*}{ Mean } & VI- & $29.5 \mathrm{~A} \mathrm{a}$ & $28.2 \mathrm{~A} \mathrm{a}$ & $20.4 \mathrm{~A} \mathrm{a}$ & $5.9 \mathrm{~A} \mathrm{a}$ & $1.9 \mathrm{~A} \mathrm{a}$ & $1.3 \mathrm{~A} \mathrm{a}$ & $69.3 \mathrm{~A} \mathrm{a}$ & $3.1 \mathrm{~A} \mathrm{a}$ & $3.0 \mathrm{~A} \mathrm{a}$ \\
\hline & VI+ & $28.4 \mathrm{~A} \mathrm{a}$ & $27.2 \mathrm{~A} \mathrm{a}$ & $15.9 \mathrm{~B} \mathrm{~b}$ & $8.1 \mathrm{~B} \mathrm{~b}$ & $3.2 \mathrm{~A} \mathrm{a}$ & $1.2 \mathrm{~A} \mathrm{a}$ & $55.0 \mathrm{~B} \mathrm{~b}$ & $3.3 \mathrm{~A} \mathrm{a}$ & $3.0 \mathrm{~A} \mathrm{a}$ \\
\hline
\end{tabular}

zYield and root quality values are the means of five replications, 20 plants per plot.

y Root quality means are expressed on a 0 to 5 scale where 5 is the best overall uniformity and appearance.

$x$ Yield means are expressed in $\mathrm{kg} \cdot \mathrm{ha}^{-1}$ for the following: total = yield of all grades; TMY (total marketable yield) $=$ No. $1 \mathrm{~s}+\mathrm{canners}+$ jumbos; No. $1 \mathrm{~s}$ $=$ roots with diameter of 5 to $<9 \mathrm{~cm}$ and length of 7.5 to $<23 \mathrm{~cm}$; canner $=$ roots with diameter of 2.5 to $<5 \mathrm{~cm}$, jumbo $=$ roots with diameter $>9 \mathrm{~cm}$, length $>23 \mathrm{~cm}$; and culls = malformed or distorted roots. Percent No.1s means are expressed as the percentage of No. 1s relative to total yield. wSPFMV represents micropropagated sweetpotato infected with Sweet potato feathery mottle virus before planting by graft-inoculation with a field isolate (VI+) and micropropagated sweetpotato, virus-indexed and tested free of known viruses (VI-).

'Mean separation within columns by Fisher's protected least significant difference test at $p<0.1$ (lower case letters) and $p<0.05$ (upper case letters) for comparisons between VI- and VI+ plants of each mericlone, and the mean of VI- and VI+ plants of all mericlones for 'Beauregard' and 'Hernandez.'

yields were reduced by $98 \%$ in VI-transplants. For each mericlone, the effects of VI- and VI+ planting materials on yield and root quality were generally consistent. For all 'Hernandez' mericlones, VI- roots were significantly $(p=0.05)$ shorter in length, wider in diameter, and lower in L/D ratios than VI+ roots (Table 2).

2001. Averaged across all 'Beauregard' mericlones, VI- planting materials produced greater TMY, No. 1 yield, and canner yields $(p=0.1)$ and percent No. 1 roots and lower jumbo yields $(p=0.05)$ than VI+ plants (Table 3). As in 2000, virus infected transplants (VI+) produced lower yields of No. 1 and percent No. 1 storage roots. VI- planting materials also produced storage roots with better overall appearance than VI+ plants $(p=0.05)$. As observed in the 2000 'Beauregard' test, the differences in yield and storage root quality attributes were generally consistent for each mericlone.

Averaged across all 'Hernandez' mericlones, VI-planting materials produced higher jumbo yields $(p=0.1)$ than VI+ plants. No other differences in yield and root quality were detected between VI- and VI+ plants averaged across mericlones. Likewise, few differences were detected between VI- and VI+ plants within a given mericlone for many of the root yield grades or qualities measured. However, L/D ratios of all mericlones were lower in VI-storage roots than VI+ storage roots (Table 2). Also, all storage roots produced by plants grown from VI+ planting materials had smaller diameters than those obtained from VI- plants.

Virus monitoring. For the 'Beauregard' and 'Hernandez' tests in 2000 and 2001, NCM-ELISA confirmed the presence of
SPFMV, while no other viruses tested were found using NCMELISA. Procedures for testing for SPVG and IVMV (Moyer et al., 2002) were not available, thus it is possible that these viruses were present.

In the 2000 'Beauregard' test, $16 \%$ of VI+ mericlones displayed virus-like symptoms (chlorotic spotting, purple ringspots, chlorotic and purple vein banding) while all VI-mericlones remained symptomless 4 WAP (Fig. 1A). By 5 WAP $\approx 58 \%$ of the VI- and $75 \%$ of the VI+ plants were symptomatic, while by $6 \mathrm{WAP}$, the percentage of both VI- and VI+ symptomatic plants had reached almost $85 \%$. Thereafter, the increase in symptomatic plants for the VI- and VI+ plots increased at the same rate.

In the 2000 'Hernandez test, symptomatic plants were not apparent in the VI- or VI+ plots 4 WAP (Fig. 1B). However, symptomatic plants were observed in the VI- and VI+ plots by 5 WAP. The percentage of symptomatic plants increased at similar rates through $10 \mathrm{WAP}$, when $100 \%$ of the VI+ and VI- plants of 'Hernandez' became symptomatic at 10 WAP.

In the 2001 'Beauregard' test, symptomatic plants were recorded in $3 \%$ of VI+ plants 1 WAP. By 2 WAP, the percentage of symptomatic plants was over $50 \%$ in the VI+ plots, while only $2 \%$ of VI- plants displayed foliar symptoms associated with virus infection (Fig. 1C). By 5 WAP, $\approx 80 \%$ of the VI+ plants were symptomatic and the percentage gradually reached $100 \%$ by 9 WAP. The increase in percentage of VI- symptomatic plants was $\approx 20 \%$ per week for 5,6 , and 7 WAP and reached $100 \%$ by 9 WAP. 
Table 2. Root measurements of length, width, and length/diameter (L/D) ratios for 'Beauregard' and 'Hernandez' mericlones in 2000 and 2001 tests.

\begin{tabular}{|c|c|c|c|c|c|c|c|}
\hline \multirow[b]{2}{*}{ Mericlone } & \multirow[b]{2}{*}{ SPFMVy } & \multicolumn{3}{|c|}{$2000^{z}$} & \multicolumn{3}{|c|}{2001} \\
\hline & & Length $^{x}$ & Width & $\mathrm{L} / \mathrm{D}$ & Length & Width & $\mathrm{L} / \mathrm{D}$ \\
\hline \multicolumn{8}{|l|}{ Beauregard } \\
\hline \multirow[t]{2}{*}{ B94-14 } & VI- & 15.7 & 6.0 & 2.7 & 12.0 & 6.3 & 1.9 \\
\hline & & $* *$ & $* * *$ & $* * *$ & $*$ & NS & $*$ \\
\hline \multirow[t]{2}{*}{ B94-34 } & VI- & 16.9 & 5.9 & 2.9 & 12.5 & 5.8 & 2.2 \\
\hline & VI+ & 17.3 & 5.0 & 3.5 & 13.7 & 5.9 & 2.3 \\
\hline \multirow[t]{3}{*}{ B73 } & VI- & 15.5 & 5.7 & 2.8 & 12.3 & 6.0 & 2.1 \\
\hline & VI+ & 16.7 & 5.3 & 3.2 & 12.9 & 6.3 & 2.1 \\
\hline & & $* * *$ & $* *$ & $* * *$ & NS & NS & NS \\
\hline \multirow[t]{3}{*}{ Mean } & VI- & 16.0 & 5.8 & 2.8 & 12.3 & 7.4 & 2.1 \\
\hline & VI+ & 16.8 & 5.2 & 3.3 & 13.4 & 6.2 & 2.2 \\
\hline & & $*$ & $* * *$ & $* * *$ & $* * *$ & NS & $*$ \\
\hline \multirow[t]{3}{*}{ H98-9 } & VI- & 18.3 & 5.9 & 3.2 & 12.4 & 6.7 & 1.9 \\
\hline & VI+ & 19.2 & 5.6 & 3.5 & 17.1 & 6.4 & 2.7 \\
\hline & & $* *$ & $* *$ & $* * *$ & NS & $* *$ & NS \\
\hline \multirow[t]{3}{*}{ USDA } & VI- & 16.3 & 6.0 & 2.8 & 11.4 & 6.8 & 1.7 \\
\hline & VI+ & 18.5 & 5.1 & 3.7 & 12.4 & 6.3 & 2.0 \\
\hline & & $* * *$ & $* * *$ & $* * *$ & $* * *$ & $* * *$ & $* * *$ \\
\hline \multirow[t]{3}{*}{ Meanw } & VI- & 17.5 & 5.8 & 3.0 & 12.1 & 6.7 & 1.8 \\
\hline & VI+ & 19.0 & 5.3 & 3.6 & 13.8 & 6.3 & 2.2 \\
\hline & & $* * *$ & $* * *$ & $* * *$ & NS & $* * *$ & NS \\
\hline
\end{tabular}

${ }^{2}$ Root measurement means of five replications, 20 plants per plot (2000) and 25 plants per plot (2001).

${ }^{y}$ SPFMV represents micropropagated sweetpotato infected with Sweet potato feathery mottle virus before planting by graft-inoculation with a field isolate (VI+) and micropropagated sweetpotato, virus-indexed and tested free of known viruses (VI-).

xLength of roots were measured to the nearest $\mathrm{cm}$ from the proximal to distal end of roots and included only $2.5 \mathrm{~cm}$ of ends less than $1 \mathrm{~cm}$ in diameter. Width was measured in $\mathrm{cm}$ at the midpoint of the length measurement. L/D ratio is the length divided by diameter.

"Mean separation by least significant means test comparing VI- and VI+ plants of each mericlone.

ns, $, * *, * * *$ Nonsignificant or significant at $p<0.05,0.01$, or 0.001 , respectively.

In the 2001 'Hernandez' test, virus symptoms were not observed in the VI+ plots until 2 WAP, while the first symptoms were not observed in the VI- plots until 4 WAP (Fig. 1D). By 4 WAP, $40 \%$ of the VI+ plants displayed foliar symptoms of virus infection, while no symptoms were observed for VI- plants for the same time period. After 4 WAP, a steady increase in plants showing virus symptoms was observed for both the VI- and VI+ plots. VI+ plants showed virus symptoms on $\approx 10 \%$ more plants than VI- plants during weeks 6 and 7.

\section{Discussion}

Sweetpotato cultivar decline has been attributed to the accumulation of mutations, viruses and possibly other pathogens (Clark et al., 2002; Villordon and La Bonte, 1996). Based on our research and newly reported information of the possibilities of a complex of potyviruses, including SPFMV, infecting sweetpotatoes (Clark and Valverde, 2001; Moyer et al., 2002) it is clearly evident that viruses negatively impact sweetpotato yield and quality in the United States. Our research demonstrates that TMY, yield of No. 1s, and percent No. 1s in 'Beauregard' are decreased when a crop is established with planting materials infected with virus compared to virus-indexed seed stock. Planting virus-infected seed also results in decreased overall appearance for both cultivars, but most notably in 'Beauregard.' Likewise, transplants infected with virus consistently produced storage roots with higher L/D ratios, resulting in lower total yield, TMY and root quality of both 'Beauregard' and 'Hernandez.' The observed decrease in root diameter and root weight (yield) associated with the presence of SPFMV and/or other additional potyviruses is consistent with other reports comparing storage roots produced from SPFMV-infected plants to cuttings derived from virus free cuttings derived from meristem-tip culture. For example, Kano and Nagata (1999) found that planting SPFMV-infected plants resulted in lower yields, and the storage roots produced from the virus-infected plants possessed smaller root diameters than storage roots produced from healthy plants.

During virus monitoring, we observed that VI+ plants began to display foliar symptoms of virus infection as early as 1 WAP in 2001 and 4 WAP in 2000. It is likely that we could have observed virus symptoms 1 WAP in the 2000 trials; however, we did not start monitoring the sweetpotato plants until 4 WAP in 2000. In contrast, VI- plants did not display foliar symptoms until 5 WAP. However, it is important to note that, in both tests and during both years, all the VI- plants became infected with SPFMV by the end of the growing season. We observed that storage roots of sweetpotato were formed in sweetpotato very early in the season, as early as 3 WAP in some cases. Wilson and 
Table 3. Yield and root quality measurements for 'Beauregard' and 'Hernandez' mericlones in field trials in 2001, Cunningham Research Station, Kinston, N.C. ${ }^{2}$

\begin{tabular}{|c|c|c|c|c|c|c|c|c|c|c|}
\hline \multirow[b]{3}{*}{ Mericlone } & \multirow[b]{3}{*}{ SPFMVw } & \multirow{2}{*}{\multicolumn{7}{|c|}{ Yieldx }} & \multicolumn{2}{|c|}{ Root qualityy } \\
\hline & & & & & & & & & \multirow{2}{*}{$\begin{array}{c}\text { Shape } \\
\text { uniformity }\end{array}$} & \multirow{2}{*}{$\begin{array}{c}\text { Overall } \\
\text { appearance }\end{array}$} \\
\hline & & Total & TMY & No. 1 & Canners & Jumbos & Culls & No. $1(\%)$ & & \\
\hline \multicolumn{11}{|l|}{ Beauregard } \\
\hline B94-14 & VI+ & $26.2 \mathrm{~A} \mathrm{a}$ & $24.4 \mathrm{~A} \mathrm{a}$ & $15.2 \mathrm{Ab}$ & $6.3 \mathrm{~A} \mathrm{a}$ & $2.9 \mathrm{~A} \mathrm{a}$ & $1.9 \mathrm{~B} \mathrm{~b}$ & $57.7 \mathrm{~A} \mathrm{a}$ & $2.9 \mathrm{~A} \mathrm{a}$ & $2.6 \mathrm{Ab}$ \\
\hline \multirow[t]{2}{*}{ B94-34 } & VI- & $32.1 \mathrm{~A} \mathrm{a}$ & $30.7 \mathrm{~A} \mathrm{a}$ & $22.4 \mathrm{~A} \mathrm{a}$ & $7.8 \mathrm{~A} \mathrm{a}$ & $0.5 \mathrm{~A} \mathrm{a}$ & $1.4 \mathrm{~A} \mathrm{a}$ & $69.3 \mathrm{~A} \mathrm{a}$ & $3.5 \mathrm{~A} \mathrm{a}$ & $3.3 \mathrm{~A} \mathrm{a}$ \\
\hline & VI+ & $27.8 \mathrm{~A} \mathrm{a}$ & $25.9 \mathrm{~A} \mathrm{a}$ & $16.1 \mathrm{Ab}$ & $6.1 \mathrm{~A} \mathrm{a}$ & $3.7 \mathrm{~A} \mathrm{a}$ & $1.9 \mathrm{~A} \mathrm{a}$ & $56.4 \mathrm{~A} \mathrm{a}$ & $3.1 \mathrm{Ab}$ & $2.4 \mathrm{~A} \mathrm{~b}$ \\
\hline B73 & VI+ & $26.2 \mathrm{~A} \mathrm{a}$ & $24.1 \mathrm{~A} \mathrm{a}$ & $13.6 \mathrm{Ab}$ & $4.7 \mathrm{~A} \mathrm{a}$ & $5.8 \mathrm{~A} \mathrm{a}$ & $2.1 \mathrm{~A} \mathrm{~b}$ & $52.2 \mathrm{~B} \mathrm{~b}$ & $2.5 \mathrm{Ab}$ & $2.0 \mathrm{~B} \mathrm{~b}$ \\
\hline \multirow[t]{2}{*}{ Mean } & VI- & $31.2 \mathrm{~A} \mathrm{a}$ & $30.2 \mathrm{~A} \mathrm{a}$ & $20.3 \mathrm{~A} \mathrm{a}$ & $6.7 \mathrm{~A} \mathrm{a}$ & $3.2 \mathrm{~A} \mathrm{a}$ & $1.1 \mathrm{~A} \mathrm{a}$ & $64.7 \mathrm{~A} \mathrm{a}$ & $3.3 \mathrm{~A} \mathrm{a}$ & $3.3 \mathrm{~A} \mathrm{a}$ \\
\hline & VI+ & $26.8 \mathrm{~A} \mathrm{a}$ & $24.8 \mathrm{~A} \mathrm{~b}$ & $15.0 \mathrm{Ab}$ & $6.7 \mathrm{Ab}$ & $4.1 \mathrm{~B} \mathrm{~b}$ & $2.0 \mathrm{~A} \mathrm{a}$ & $55.4 \mathrm{~B} \mathrm{~b}$ & $2.8 \mathrm{~A} \mathrm{a}$ & $2.3 \mathrm{~B} \mathrm{~b}$ \\
\hline \multicolumn{11}{|l|}{ Hernandez } \\
\hline \multirow[t]{2}{*}{ H98-7 } & VI- & $25.3 \mathrm{~A} \mathrm{a}$ & $28.1 \mathrm{~A} \mathrm{a}$ & $14.7 \mathrm{~A} \mathrm{a}$ & $5.3 \mathrm{~A} \mathrm{a}$ & $4.8 \mathrm{~A} \mathrm{a}$ & $0.5 \mathrm{~A} \mathrm{a}$ & $58.1 \mathrm{~A} \mathrm{a}$ & $2.9 \mathrm{~A} \mathrm{a}$ & $3.0 \mathrm{~A} \mathrm{a}$ \\
\hline & VI+ & $28.8 \mathrm{~A} \mathrm{a}$ & $24.8 \mathrm{~A} \mathrm{a}$ & $20.7 \mathrm{~A} \mathrm{a}$ & $5.2 \mathrm{~A} \mathrm{a}$ & $2.2 \mathrm{Ab}$ & $0.7 \mathrm{~A} \mathrm{a}$ & $69.5 \mathrm{~A} \mathrm{a}$ & $2.6 \mathrm{~A} \mathrm{a}$ & $2.9 \mathrm{~A} \mathrm{a}$ \\
\hline \multirow[t]{2}{*}{ Mean } & VI- & $25.2 \mathrm{~A} \mathrm{a}$ & $24.6 \mathrm{~A} \mathrm{a}$ & $15.4 \mathrm{~A} \mathrm{a}$ & $5.5 \mathrm{~A} \mathrm{a}$ & $3.6 \mathrm{~A} \mathrm{a}$ & $0.7 \mathrm{~A} \mathrm{a}$ & $60.8 \mathrm{~A} \mathrm{a}$ & $3.3 \mathrm{~A} \mathrm{a}$ & $3.0 \mathrm{~A} \mathrm{a}$ \\
\hline & $\mathrm{VI}+$ & $25.1 \mathrm{~A} \mathrm{a}$ & $24.2 \mathrm{~A} \mathrm{a}$ & $16.4 \mathrm{~A} \mathrm{a}$ & $5.8 \mathrm{~A} \mathrm{a}$ & $2.0 \mathrm{~A} \mathrm{~b}$ & $0.9 \mathrm{~A} \mathrm{a}$ & $63.4 \mathrm{~A} \mathrm{a}$ & $2.8 \mathrm{~A} \mathrm{a}$ & $2.8 \mathrm{~A} \mathrm{a}$ \\
\hline
\end{tabular}

zYield and root quality values are the means of five replications, 25 plants per plot.

yoot quality measurements are recorded on a 0 to 5 scale where 5 is the best overall uniformity and appearance.

$x$ Yield means are expressed in $\mathrm{kg} \cdot \mathrm{ha}^{-1}$ for the following: total = yield of all grades; TMY (total marketable yield) = No. $1 \mathrm{~s}+\mathrm{canners}+$ jumbos; No. $1 \mathrm{~s}$ $=$ roots with diameter of 5 to $<9 \mathrm{~cm}$ and length of 7.5 to $<23 \mathrm{~cm}$; canner $=$ roots with diameter of 2.5 to $<5 \mathrm{~cm}$, jumbo $=$ roots with diameter $>9 \mathrm{~cm}$, length $>23 \mathrm{~cm}$; and culls = malformed or distorted roots. Percent No.1s means are expressed as the percentage of No.1s relative to total yield. wSPFMV represents micropropagated sweetpotato infected with Sweet potato feathery mottle virus before planting by graft-inoculation with a field isolate (VI+) and micropropagated sweetpotato, virus-indexed and tested free of known viruses (VI-).

${ }^{v}$ Mean separation within columns by Fisher's protected least significant difference test at $p<0.1$ (lower case letters) and $p<0.05$ (upper case letters) for comparisons between VI- and VI+ plants of each mericlone, and the mean of VI- and VI+ plants of all mericlones for 'Beauregard' and 'Hernandez.'

Lowe (1973) have also observed that root initiation can occur as early as 3 WAP. They reported that at 3 WAP, secondary vascular tissues are formed in the cambium resulting in a regular cylinder of cambium being formed, producing uniform root thickening. In our study, both yield and diameters of storage roots derived from VI+ planting materials were consistently lower than those obtained from uninfected planting stock. We speculate that the initial presence of virus inoculum in transplants may interfere with subsequent cambial activity and reduce root thickening in the developing storage roots resulting in smaller storage root diameters, higher L/D ratios, and reduced overall appearance. This phenomenon needs to be investigated further.

The variability in differences observed in yield and quality attributes for the 'Beauregard' and 'Hernandez' mericlones in 2000 and 2001 are probably due, in part, to environmental factors. Sweetpotato yield is greatly influenced by environment (Bacusmo et al., 1988; Carpena et al., 1982; Collins et al., 1987; Kannua and Floyd, 1988; Ngeve and Bouwkamp, 1993) and the widely differing environmental conditions in the 2000 and 2001 experiments undoubtedly impacted yield in the VI- and VI+ plants of the 'Beauregard' and 'Hernandez' mericlones. In 2001, heavy rains produced water logged soils in the 'Beauregard' test plots, and most markedly in the 'Hernandez' test plots, where water was standing between the rows at 4 and 7 WAP. In 2000 , however, rainfall was better distributed and excess water in soils was not observed. Flooding has been reported to reduce the number, size, and diameter of sweetpotato roots ( $\mathrm{Li}$ and $\mathrm{KaO}$, 1985). In 2000, L/D ratios were higher in roots produced by VI+ plants than VI- plants in both 'Beauregard' and 'Hernandez.'
The mean length of roots produced by both VI- and VI+ plants of each cultivar were at least $3 \mathrm{~cm}$ longer in 2000 than in 2001 (Table 3 ). In addition to these observations, our research suggests that the cultivar Hernandez is less susceptible to SPFMV, or it expresses symptoms later after the onset of infection, compared to 'Beauregard'. At least 50\% of initial SPFMV symptoms on VI+ plants of 'Hernandez' were recorded at least one week later in 2000 and 3 weeks later in 2001 than those were recorded for VI+ plants of 'Beauregard' (Fig. 1). In addition, russet crack symptoms were observed in 'Beauregard' storage roots but not in 'Hernandez' (data not presented).

Our NCM-ELISA assays confirmed the presence of SPFMV in plants sampled from both 'Beauregard' and Hernandez' trials in 2000 and 2001. Tests using NCM-ELISA assays for SPMMV, SwPLV, SPCFV, SPMSV, C-6 virus, SPCSV, and SPCaLV also yielded negative results indicating that these viruses were not present in our field plots. However, several new potyviruses infecting sweetpotato including SPVG and IVMV have recently been reported in the United States. Thus, they may have been present in the current study as the source of SPFMV used for these experiments was obtained from foundation seed fields and was not isolated. Therefore, any potential virus combinations or strains, if present in North Carolina production areas, were included in the study.

Of about 20 viruses that infect sweetpotato, 9 [SPFMV, SPCSV, Sweet potato leaf curl virus (SPLCV), Ipomoea leaf curl virus (ILCV), Sweet potato virus G (SPVG), Ipomoea vein mosaic virus (IVMV), Cucumber mosaic virus (CMV), and Tobacco mosaic virus (TMV)] have been isolated from sweetpotato in 


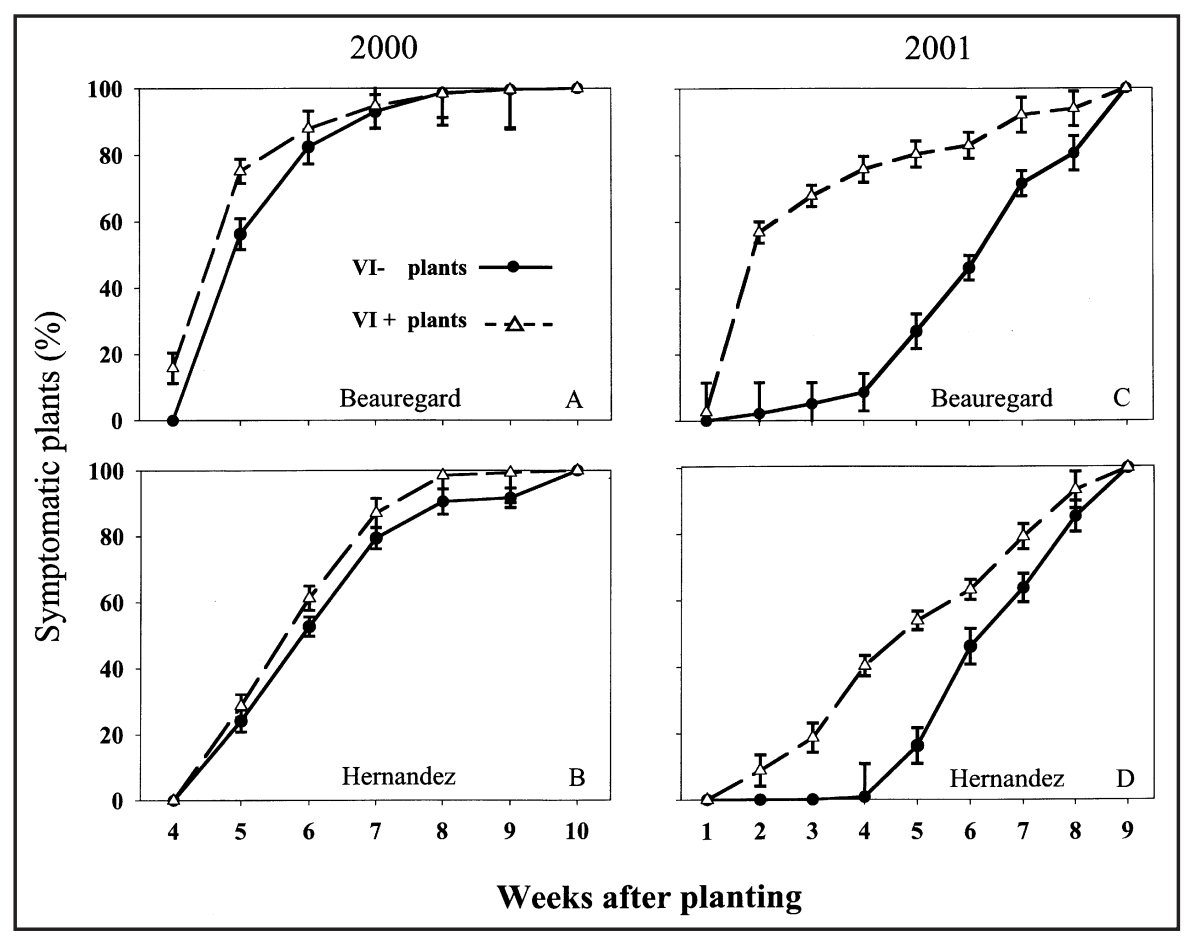

dez', but this clone suffers from other flaws. In commercial sweetpotato production in the United States, one cultivar has often dominated the industry (Schultheis et al., 1999). Currently 'Beauregard' is the predominant clone grown in the United States. Growers who choose to plant 'Beauregard' will benefit from micropropagated, virus-tested plants or adventitious propagules produced from seed roots of plants that have avoided virus reinfection. However, production of certified seed roots (produced from plants not infected with SPFMV and/or other potyviruses will most likely be difficult given the rapid rate of infection of SPFMV in the field observed in this study. Based on our observations, certified seed production programs will require highly stringent isolation measures in order to produce virus-free seed for growers in the field.

\section{Conclusions}

Viruses have been noted to contribute to cultivar decline in sweetpotato worldwide. In this study, the presence of SPFMV contrib-

Fig. 1. Weekly percentage of Sweet potato feathery mottle virus (SPFMV) symptom expression in plants of 'Beauregard' and 'Hernandez' mericlones infected with SPFMV before planting (VI+) and mericlones, initially virus-indexed (VI-) and infected with SPFMV during the growing season for 2000 and 2001 (Cunningham Research Station, Kinston, N.C.). Mean weekly percentages of 'Beauregard'(A) and 'Hernandez' (B) mericlones of each VI- and VI+ plants displaying SPFMV symptoms during the growing season in 2000 beginning 4 weeks after planting (WAP). Percentages are means of five replications 20 plants per plot. Mean weekly percentages of 'Beauregard' $(\mathbf{C})$ and 'Hernandez' (D) mericlones of each VI- and VI+ plants displaying SPFMV symptoms during the growing season in 2001 beginning 1 WAP. Percentages are means of five replications 25 plants per plot.

the United States (Brunt et al., 1996; Clark et al., 1997; Clark and Valverde, 2001; Cohen et al., 1988; Lotrakul et al., 1998; 2001; Moyer et al., 2002; Moyer and Kennedy, 1978; Pio-Ribeiro, et al., 1996; Sim et al., 2000; Valverde and Clark, 1997). Until recently, SPFMV was the only virus reported to occur in commercial sweetpotato production fields in the United States. Sweetpotato samples from research stations and grower fields in North Carolina have been tested for SPLCV, ILCV, SPVG, and IVMV since the completion of this study. These preliminary tests indicate that SPVG and IVMV may be present in fields in North Carolina (Moyer et al., 2002; unpublished data). No commercial sweetpotato samples have tested positive for SPLCV and ILCV, while several ornamentals and breeding lines have tested positive for SPLCV (unpublished data). Further investigation is needed in determining the extent of these viruses in North Carolina and their effect on yield and root quality.

From a production standpoint, most growers in the United States use adventitious propagation methods to produce transplants for the next crop (Dangler, 1994). If adventitious propagules used for transplanting were derived from roots of plants that had been infected with SPFMV and other viruses in the previous growing season, a decline in yield and root quality can be expected when a susceptible cultivar such as 'Beauregard' is used. Growers who prefer adventitious propagation because of rapid increase of transplants will most likely need a cultivar that is resistant or tolerant to the U.S. potyvirus complex, which may be the case for 'Hernan- uted to a decrease in the yield and root quality of 'Beauregard' and 'Hernandez' in a single season, but more significantly with 'Beauregard.' In a companion study comparing micropropagated, virus-indexed 'Beauregard' mericlones, B94-14 and B94-34, to the same mericlones adventitiously propagated over five field generations, we observed that yield and root quality decreased with increased cycles of adventitious propagation (Bryan, 2002; Bryan et al., 2003). Although, this study indicated that a gradual, but significant, decrease in yield and root quality occurs over time; the presence of SPFMV and other viruses in adventitious propagules may account for the larger, more significant decrease after the first cycle of adventitious propagation. The development and use of cultivars resistant or tolerant to SPFMV and other viruses are needed to minimize the rate of cultivar decline in sweetpotato.

\section{Literature Cited}

Averre, C.W., J.A. Abad, and W.R. Jester. 1993. Sweetpotato virus-free micropropagated Jewel and Beauregard evaluation 1990-1991. Biol. Cult. Tests Control Plant Dis. 8:31.

Bacusmo, J.L., W.W. Collins, and A. Jones. 1988. Comparison of methods of determining stability and adaptation of sweetpotato. Theor. Applied Genet. 75:492-497.

Brunt, A.A., K. Crabtree, M.J. Dallwitz, A.J. Gibbs, L. Watson, and E.J. Zurcher. (eds). 1996 and onwards. Plant viruses online: Descriptions and lists from the VIDE database. 20 th Aug. 1996. http://biology.anu.edu.au/ Groups/MES/vide/.

Bryan, A.D. 2002. Impact of Sweet potato feathery mottle virus and micropropagation on yield, root quality, and virus incidence in commercial sweetpotato production systems. MS thesis. N.C. State Univ., Raleigh.

Bryan, A.D., Z. Pesic-VanEsbroeck, J.R. Schultheis, K.V. Pecota, W.H. Swallow and G.C.Yencho. 2003. Cultivar decline in sweetpotato: I. impact of micropropagation on yield, storage root quality and virus incidence in 'Beauregard.' J. Amer. Soc. Hort. Sci. 128:846-855.

Carpena, A.L., E.T. Rebancos, P.H. Manguiat, M.M. Zalmeda, G.E. Sajise, and J.L. San Pedro. 1982. Stability of yield performance of some sweetpotato cultivars. Philippine Crop Sci. J. 5:30-33.

Clark, C.A. and J.W. Moyer. 1988. Compendium of sweetpotato diseases. 
APS Press, Minneapolis.

Clark, C.A., M.W. Hoy, and R.A. Valverde. 1997. The evolving disease situation of sweetpotatoes. La. Agr. 40:15-19.

Clark, C.A. and R.A. Valverde. 2001. Identifying the role of viruses in sweetpotato cultivar decline in Louisiana, USA. p. 62-69. In: Proceedings of the international workshop on sweetpotato cultivar decline study. 8-9 Sept. 2000, Miyakonojo, Japan. http://ss.mykz.affrc.go.jp/ Workshop/WS2000/workshop/index workshop.html.

Clark, C.A., R.A. Valverde, S. Fuentes, L.F. Salazar, and J.W. Moyer 2002. Research for improved management of sweetpotato pests and diseases, p. 103-112. In: T. Ames (ed.). Proceedings of the first international conference on sweetpotato food and health for the future. Acta Hort. 583.

Cohen, J., E. Loebenstein, and S. Siegel. 1988. Infection of sweetpotato by Cucumber mosaic virus depends on the presence of Sweet potato feathery mottle virus. Plant Dis. 72:583-585.

Collins, W.W., L.G. Wilson, S. Arrendell, and L.F. Dickey. 1987. Genotype $\times$ environment interactions in sweetpotato yield and quality factors. $J$. Amer. Soc. Hort. Sci. 112:579-583.

Dangler, J.M. 1994. Sweetpotato foundation programs provide sweetpotato growers with high quality pathogen-free stock. Compendium of sweetpotato foundation programs. HortTechnology. 4:224.

Hahn, S.K. 1979. Effects of viruses (SPVD) on growth and yield of sweetpotato. Expt. Agr. 15:253-256.

Hartman, H.T., D.E. Kester, F.T. Davies, Jr., and R.L. Geneve. 1997. Plant propagation: Principles and practices. $6^{\text {th }}$ ed. Prentice Hall, Englewood Cliffs, N.J.

Jester, W.R., C.W. Averre, and J.R. Schultheis. 1994. Russet crack-like symptoms in 'Beauregard 'sweetpotato reduced by virus indexing and micropropagation. HortScience 29:727 (abstr.).

Kannua, M.B. and C.N. Floyd. 1988. Sweetpotato genotype $\times$ environment interactions in the highlands of Papua New Guinea. Trop. Agr. (Trinidad). 65:9-16.

Kano, Y. and R. Nagata. 1999. Comparison of rooting ability of virus infected and virus-free cuttings of sweetpotatoes (Ipomoea batatas Poir.) and an anatomical comparison of the roots. J. Hort. Sci. Biotechnol. 74:785-790.

La Bonte, D.R., W.A. Mulkey, C.A. Clark, L.H. Rolston, J.M. Cannon, P.W. Wilson, and P.C. St. Amand. 1992. 'Hernandez' sweetpotato. HortScience 27:377.

Liao, C.H., M.L. Cumg, and T. Hsin-Sheng. 1983. Influence of sweetpotato viruses on the performances of some agronomic characteristics of sweetpotatoes. J. Agr. Res. China. 32:228-232.

Li, L., and C.H. Kao. 1985. Stress physiology in sweetpotato. 1. Flooding effects on sweetpotatoes. J. Agr. Assn., China. 132:115-120.

Lotrakul, P., R.A. Valverde, C.A. Clark, J. Sim, and R. De la Torre. 1998. Detection of a geminivirus infecting sweetpotato in the United States. Plant Dis. 82:1253-1257.

Lotrakul, P., R.A. Valverde, and C.A. Clark. 2001. Properties of a begomovirus isolated from sweetpotato infected with Sweet potato leaf curl virus. Phytopatholology 91:S56.

Milgram, M.J., J. Cohen, and G. Loebenstein. 1996. Effects of Sweet potato feathery mottle virus and Sweet potato sunken vein virus on sweetpotato yields and rates of re-infection of virus free planting material in Israel. Phytoparasitica 24:189-193.

Moyer, J.W. and G.G. Kennedy. 1978. Purification and properties of Sweet potato feathery mottle virus. Phytopathology 68:998-1004.

Moyer, J.W. G.V.H. Jackson, and E.A. Friason. 1989. FAO/IBGR technical guidelines for the safe movement of sweetpotato germplasm. FAO/UN, IBGR, Rome.
Moyer, J.W. and L.F. Salazar. 1989. Viruses and virus-like disease of sweetpotato. Plant Dis. 73:451-455.

Moyer, J.W., J.A. Abad, J. New, and J. Bell. 2002. Isolation, identification and detection of undescribed RNA sweetpotato viruses, p. 121-127. In: T. Ames (ed.). Proceedings of the first international conference on sweetpotato food and health for the future. Acta Hort. 583.

Mukiibi, J. 1977. Effect of mosaic on the yield of sweetpotatoes in Uganda. Proc. 4th Intl. Soc. Trop. Roots CIAT Cali, Columbia, p. 169-170.

Ngeve, J.M. 1990. Yield stability and yield depression in sweetpotato cultivars susceptible to the Sweet potato virus disease. J. Hort. Sci. 65:225-230.

Ngeve, J.M. and J.C. Bouwkamp. 1991. Effects of Sweet potato virus disease (SPVD) on yield of sweetpotato. Expt. Agr. 27:221-225.

Ngeve, J.M. and J.C. Bouwkamp. 1993. Comparison of statistical methods to assess yield stability in sweetpotato. J. Amer. Soc. Hort. Sci. 118:304-310.

Olivero, C.A. and T. Oropeza. 1985. Effects of the feathery mottle virus on yield and other agronomic parameters of cultivated sweetpotato. Agron. Trop. 35:167-172.

Pio-Ribeiro, G., S. Winter, R.L. Jarret, J.W., Demski, and R.I. Hamilton. 1996. Detection of sweetpotato virus-disease associated closterovirus in a sweetpotato accession in the United States. Plant Dis. 80:551-554.

Pozzer, L., J.B.C. Silva, A.N. Dusi, and E.W. Kitajima. 1995. Performance of micropropagated sweetpotato plants after two field propagations and rate of reinfection by Sweet potato feathery mottle virus. Fitopatol. Bras. 20:464-468.

Rolston, L.H., C.A. Clark, J.M. Cannon, W.M. Randle, E.G. Riley, P.W. Wilson, and M.L. Robbins. 1987. 'Beauregard' sweetpotato. HortScience 22:1338-1339.

SAS Institute. 1998. SAS/STAT users' guide, release 7.0. SAS Inst, Cary, N.C.

Schultheis, J.R. 1994. Virus-free micropropagated plants and clone effects on sweetpotato yield. HortScience 28:727 (abstr.).

Schultheis, J.R., W.W. Collins, and C.W. Averre. 1994. Micropropagation, a means to enhance sweetpotato yield and quality. HortScience 29:466 (abstr.).

Schultheis, J.R., S.A. Walters, D.E. Adams, and E.A. Estes. 1999. In row plant spacing and date of harvest of 'Beauregard' sweetpotato affect yield and return on investment. HortScience 34:1229-1233.

Sim, J., R.A. Valverde, and C.A. Clark. 2000. Detection of Sweet potato chlorotic stunt crinivirus. Phytopathology 20:S72.

Souto, E. R., J. Sim, J. Chen, R.A. Valverde, and C.A. Clark. 2003. Properties of strains of Sweet potato feathery mottle virus and two newly recognized potyviruses infecting sweetpotato in the United States. Plant Dis. (in press).

Templeton-Somers, K.M. and W.W. Collins. 1986. Field performance and clonal variability in sweetpotatoes propagated in vitro. J. Amer. Soc. Hort. Sci. 111:689-694.

Valverde, R.A. and C.A. Clark. 1997. Whiteflies transmit new virus disease in Louisiana sweetpotatoes. La. Agr. 40:28-29.

Villordon,A.Q. and D.R. LaBonte. 1995. Variation in randomly amplified DNA markers and storage root yield in 'Jewel' sweetpotato clones. J. Amer. Soc. Hort. Sci. 120:734-740.

Villordon, A.Q. and D.R. LaBonte. 1996. Genetic variation among sweetpotatoes propagated through nodal and adventitious sprouts. J. Amer. Soc. Hort. Sci. 121:170-174.

Wilson, L.G. and C.A. Averre. 1989. Growing and marketing quality sweet potatoes. N.C. Agr. Ext. Serv., N.C. State Univ., Raleigh.

Wilson, L.A. and S.B. Lowe. 1973. The anatomy of the root system in West Indian sweet potato cultivars. Ann. Bot. 37:633-43. 